\title{
Financial Deepening and Bank Performance: A Case Study of Selected Commercial Banks in Nigeria
}

\author{
S. O. Olawumi ${ }^{1}$, L. A. Lateef ${ }^{2}$, E. O. Oladeji ${ }^{1}$ \\ ${ }^{1}$ Department of Banking \& Finance, The Oke-Ogun Polytechnic, Saki, Nigeria \\ ${ }^{2}$ Department of Accountancy, The Oke-Ogun Polytechnic, Saki, Nigeria \\ Email: olustephen2@hotmail.co.uk, lukuman.lateef2013@gmail.com
}

How to cite this paper: Olawumi, S.O., Lateef, L.A. and Oladeji, E.O. (2017) Financial Deepening and Bank Performance: A Case Study of Selected Commercial Banks in Nigeria. Journal of Mathematical Finance, 7, 519-535.

https://doi.org/10.4236/jmf.2017.73028

Received: April 26, 2017

Accepted: June 16, 2017

Published: June 19, 2017

Copyright ( 2017 by authors and Scientific Research Publishing Inc. This work is licensed under the Creative Commons Attribution International License (CC BY 4.0).

http://creativecommons.org/licenses/by/4.0/ (c) (i) Open Access

\begin{abstract}
This paper titled, "Financial Deepening and Performance of Selected Commercial Banks in Nigeria" examined the extent to which financial deepening has affected the performance of selected Nigerian commercial banks in terms of profitability. The study empirically investigated the relationship between financial deepening and bank performance using financial deepening $\left(\mathrm{M}^{2} / \mathrm{GDP}\right)$, ratio of credit to private sector-GDP, ratio of deposit liabilities-GDP as variables of financial deepening while performance measure of interest is profitability. The study adopted descriptive research design to explore the relevance of financial deepening on banks performance. The data for this study were sourced secondarily. Methods of descriptive and empirical analysis were used to analyze the data, while relevant statistics were used to evaluate the models for consistency or otherwise with expectations, statistical significance and explanatory power. Findings revealed that each component of financial deepening indicators has a strong relationship and are statistically significant; this provides empirical evidence that financial deepening made positive contributions to the level of profitability of the selected commercial banks in $\mathrm{Ni}$ geria. This paper concludes that contributions of each component of financial deepening to selected commercial banks performance is strong and are statistically significance. Thus, the paper has bridged the gap between economists' belief and empirical work in the literature by establishing a strong and positive contribution of financial deepening to selected commercial banks profitability.
\end{abstract}

\section{Keywords}

Banks, Deepening, Finance, Performance, Profitability 


\section{Introduction}

\subsection{Background to the Study}

Banks played vital role in the growth and development process of a nation. Traditionally, the role of banks in an economy is to facilitate an efficient payments system and to serve as a conduit for the implementation of monetary policies [1]. A bank's primary purpose is financial intermediation; accepting deposits, making loans at variety of maturities either fixed or at variable rates and make money through interest rates spread by charging for services provided [2]. Commercial banks in Nigeria have undergone immense regulatory and technological changes since the attainment of democracy in 1960 as this marked the establishment of formal money and capital markets, and portfolio [3]. Nigerian banks are faced with increasingly keen competition and rising costs as a result of regulatory requirements, financial and technological innovations, bank distress and other challenges which have dramatic effects on their performances. The reforms in the financial system in Nigeria, which heightened with the 1986 deregulation, affected the level of financial deepening in the country and the level relevance of the financial system to economic development [4]. One of the reforms - the consolidation exercise is one of the major highlights in Nigerian financial sector development in recent years. Specifically, increasing the maximum paid-up capital is expected to enhance the deepening of banking services in the country. This is expected to enable Nigerian banks to offer services to the segments of the society that had remained outside the coverage of the existing banking system. The proponent of consolidation [5] opined that banks that could not solely meet the recapitalization requirement should engage in merger and acquisition, and, as such, recapitalization is seen as an important component of consolidation. [6] asserts that, banking sector reforms and recapitalization have resulted from deliberate policy response to correct perceived or intending banking sector crises and subsequent fractures. There were eighty nine (89) banks operating predominantly in the urban centres as at 2004. They were characterized by structural and operational weakness of low capital base, dominance of few banks, insolvency and illiquidity, over dependence on public sector deposits and foreign exchange trading, poor asset quality, poor corporate governance and a system characterized by low public confidence [7]. In a nutshell, the banks had two things in common-small size and unethical practices [8]. As such, the banks could not effectively support the real sector of the economy. Reforms are therefore predicated on the need for re-orientation and repositioning of an existing status quo in order to attain an effective and efficient state. According to [9], banking reforms involve several elements that are unique to each country based on historical, economic and institutional imperatives. Countries reform their banking sectors for a number of reasons including structural, capitalization and ownership issues [10]. Hence, financial deepening becomes inevitable in the light of global dynamic exigency and emerging landscape. Consequently deepening of the banking sector is required to enhance its competitiveness and capacity to play a fundamental role in development and the finance of investment 
opportunities in all sectors of the economy [3]. Therefore, financial deepening is a pre-condition for economic growth [11].

\subsection{Statement of Problem}

Financial deepening in Nigeria banking system has grown and become a subject of debate in recent years. [12] and [13] opine that "although Financial Deepening is essential for growth, it is only an essential lubricant but not a substitute for the machine." Also, the fundamental question that has pre-occupied researchers is why is it that less developed countries such as Nigeria and Ghana have much lower of financial depth than high and middle income countries? The empirical performance literature has come with different factors, such as: institutional developments, resource endowment, ethnic and religious diversity among others cutting across different countries [14]. Another critical factor that has begun to receive considerable attention more recently is the role of financial deepening on bank performance especially in the wake of distress of bank and global economic and financial meltdown. It therefore seems that policies to develop the financial sector would be toward raising bank performance. In fact, much of financial deepening policies are aimed at enhancing bank performance but the success of these policies remains pale and subject of continued debate. While economists have a widespread believe on the central role of financial deepening on bank performance theoretically, empirical works supporting this concept are conflicting. For instance, the study of [15] revealed that much of financial deepening often lead to financial excesses. Herve, asked, "What could happen if financial deepening gets out of control (going too fast)?" This implies that too much of financial deepening or excessive financial deepening also poses a threat to economic growth and development. The problem now is how to determine the appropriate level of financial deepening suitable for bank performance, economic growth and development.

Also, to a great extent, empirical works, such as: [16] [17] [18] [19] on the relationship between financial deepening and economic growth were available without having due consideration to the 'lubricant' that fuelled economic growth which is banks' performance.

This study intends to bridge the gap, between belief as shared by economists and empirical works in the literature. This, the researcher intends to do, by empirically investigating the relationship between financial deepening and bank performance using ratio of money supply-GDP (broad money), ratio of credit to private sector-GDP, ratio of deposits liabilities of commercial banks-GDP as variables of financial deepening while performance measure of interest is profitability.

\subsection{Research Questions}

The main question this study intends to answer is: What is the extent to which financial deepening has particularly affected the performance of banks in the period covered by this research? 
The specific questions are:

1. How has the financial deepening $\left(\mathrm{M}_{2} / \mathrm{GDP}\right)$ impacted on the profit level of the selected banks?

2. What relationship exists between the ratio of credit to private sector-GDP and profits of the selected banks?

3. What is the extent to which the ratio of deposit liability-GDP affected the profits of the selected banks?

\subsection{Objectives of the Study}

The main objective of this study is to establish the impact of financial deepening on the performance of the selected banks. The specific objectives are to:

1. Examine if financial deepening $\left(\mathrm{M}_{2} / \mathrm{GDP}\right)$ impacted on the profits of selected banks;

2. Examine the relationship between ratio of credit to private sector-GDP and profitability of the selected banks and;

3. Determine the extent to which ratio of deposit liability-GDP affected profitability of the selected banks.

\subsection{Hypotheses}

The central hypothesis of this study is to establish the effect of financial deepening on banks' performance.

The specific hypotheses are:

$\mathrm{HO}_{1}$ : Financial deepening $\left(\mathrm{M}_{2} / \mathrm{GDP}\right)$ ratio has not significantly impacted on profitability of the selected banks.

$\mathrm{HO}_{2}$ : There is no significant relationship between ratio of credit to private sector-GDP and profitability of the selected banks.

$\mathrm{HO}_{3}$ : The ratio of deposit liability-GDP has not significantly affected the profitability of the selected banks.

\subsection{Justification of the Study}

Although most studies have found that financial development contributes to bank performance, they have not ended the debate on the extent of the relationship between financial deepening and bank performance. [20] constructed an econometric model which is closely linked to the "Korean banking model." The main prediction of their long-term financial deepening equation is that financial repression has a positive impact on the volume of bank loans. [21] found differing effects of banking sector control on financial development in a number of developing countries, such as India, Nepal, the Republic of Korea, the Philippines, and Thailand. In the case of India, [22] estimated a conditional error correction model for financial deepening, against the use of non-financial measures, [23], in his study of the evaluation of performance of conventional banks in Pakistan and found that financial repression indices (interest rate control index, index of other financial sector restrictions in the form of reserve requirements, minimum liquidity requirements, and directed credit programs) exhibited sig- 
nificant influence of $(-0.0465)$ on financial deepening. The econometric investigation of the effect of individual repression policies shows that interest rate controls as well as other controls have a significant negative effect on financial deepening equal respectively to -0.0154 and -0.0083 . It is expected that the outcome of this research will shed more light on the role that financial deepening could play in enhancing bank performance in Nigeria. If as a result of the development in the financial system bank's performance is positively affected, then, considerable financial deepening rate may likely improve the performance of banks. This study tends to close the gap between economists belief and empirical works in the literature by investigating empirically the relationship between financial deepening and bank performance thereby contributing to knowledge.

\subsection{Conceptual Framework}

In the recent past, financial deepening has been conceptualized and defined by various authors, researchers, and organizations. Financial deepening has been defined as an increase in the supply of financial assets in the economy [24]. It includes the aggregate or wide range of financial assets that are available in the economy. Financial deepening also implies the ability of financial institutions to effectively mobilize savings for investments. The growth of domestic savings provides the real structure for the creation of diversified financial claims. Financial deepening generally entails an increased ratio of money supply to Gross Domestic Product [25]. Financial deepening/development thus involve the establishment and expansion of institutions, instruments and growth process. [26], describes financial deepening as increased financial services geared to all levels of the society.

[11] defined financial deepening as an effort aimed at developing the financial system that is evident in increased financial instrument/assets in the financial markets-money and capital markets, leading to the expansion of the real sector of the economy. Obviously, it is the effort of developing countries to achieve growth through financial intermediation.

Within the finance-growth nexus literature, [14] argued that financial intermediaries mobilize pool and channel domestic savings into productive capital and by doing so they contribute to economic growth. If this view is to be accepted, then a competitive and well-developed banking sector must be an important contributor to (regional or national) economic growth.

The definition of financial deepening reflects the share of money supply to GDP. The most classic and practical indicator related to financial deepening is the ratio of M2/GDP which means the share of M1+ all time-related deposits and non-institutional money market funds to GDP in a certain year [14]. Financial deepening is thus measured by relating monetary and financial aggregates such as M1, M2 and M3 to Gross Domestic Product (GDP). M1: Technically defined, is the sum of: the tender that is held outside banks, travelers' cheques, checking accounts (but not demand deposits), minus the amount of money in the Federal Reserve float. 
M2: The sum of: M1, savings deposits (this would include money market accounts from which no checks can be written), and small denomination time deposits.

M3: M2 plus the large time deposits.

M1, M2, M3 are measure of money supply, that is the amount of money in circulation at a given time. Generally, the types of commercial bank money that tend to be valued at lower amounts are classified in the narrow category of M1 while the types of commercial bank money that tend to exist in larger amounts are categorized in M2 and M3, with M3 having the largest. The terms M1, M2, M3 refers to monetary aggregates. For quite some time it was thought that there was a perfect one to one relationship between these numbers and the rates of inflation. Recently, the relationship seems to have broken down, and the money supply numbers have lost some of their appeal to market participants.

Conceptually, financial depth is often understood to mean that: i) sectors and agents are able to use a range of financial markets for savings and investment decisions, including at long maturities (access); ii) financial intermediaries and markets are able to deploy larger volumes of capital and handle larger turnover, without necessitating large corresponding movements in asset prices (market liquidity); and iii) the financial sector can create a broad menu of assets for risk-sharing purposes (hedging or diversification). In other words, deep markets allow savers to invest in a broad range of quality investment and risk-sharing instruments and allow borrowers to likewise tap a broad range of financing and risk management instruments ([27] [28]).

The commonly used measures of financial deepening include ratio of money supply to GPD, ratio of domestic credit to GDP, the size of non-bank institutions to the financial system, degree of monetization, the size of currency outside the bank, ratio money supply to GDP and ratio of domestic credit to GDP [29].

Financial deepening generally entails an increased ratio of money supply to Gross Domestic Product [30]. The sum of all the measures of financial assets gives us the approximate size of financial deepening. That means that the widest range of such assets as broad money, liabilities of non-bank financial intermediaries, treasury bills, and value of shares in the stock market, money market funds and others will have to be included in the measure of financial deepening $[4]$.

\subsection{Theoretical Literature Review}

There are various theories and literatures on financial deepening and economic growth in Nigeria, with few studies on financial deepening and bank's performance, Hence, efforts are geared towards reviewing these theories for the purpose of theoretical discourse.

\subsection{The Mckinnon/Shaw Theory}

The theoretical specification of the financial deepening equation draws on the literature of finance and development which postulate a symbiotic relationship 
between the evolution of the financial system and the development of the real economy. The literature on this relationship predicts that financial deepening depends on real income and real interest rate. This is predicted by both the McKinnon and Shaw models and in the endogenous growth literature.

However, the McKinnon/Shaws approach suggests that any distortion and limitation on the banking sector, such as interest rate controls, reserve and liquidity requirement, and government rationing of available credit to so-called priority sectors, inhibit financial development mainly by depressing the interest rate ([31] [32] [33] [34] [35]). The deficiency in the amount of savings due to such repressive measures thwarts economic development through the perverse effects on the volume and the quantity of investment. Thus, the main argument of McKinnon and Shaw is that financial repression has a detrimental effect on financial development, hence on bank performance. Mckinnon and Shaw believes that financial repression needs to end in emerging countries and advocate for financial liberalization. They opined that countries need to develop its financial sphere to increase its real growth. Financial repression implies a series of constraints: the necessity for banks to have no remunerated reserves in the central banks, too low interest rates for savers etc. that are so strong that financial sphere cannot be developed. For this economists are of the opinion that financial repression leads to domestic agents to prefer having unproductive assets or no monetary assets rather than depositing assets in the bank. Based on this reason there are not enough funds to be lent in the economy, which create an obstacle for investment and thus for growth. Consequently only free markets can ensure an optimal savings allocation. They also argued that financial repression was imposing major costs on the countries that practiced it in the sense that the submarket real interest rate would tend to repress the level of savings and thereby investment. In addition the failure to ration credit by price would result in an in efficient allocation of what savings were. Growth would suffer on both counts: too little would be allocated to those uses promoting the best return, and thus would not contribute as much as potentially possible to the rate of growth. Critics challenged the likelihood of these benefits and contended that financial liberalization might nurture financial crisis.

They also contended that the policy of low interest rates was considered important avenue for promoting investment by keeping interest costs low. They however showed that the policy of controlled or administered interest rates was tantamount to "financial repression" which is a general distortion in financial prices like interest rates that reduces the real value of financial assets. Thus, the overall volume of savings decreases and investment is naturally and adversely affected. The policy prescription for financially repressed economy in Mackinnon and Shaw models is than to raise institutional interest rates or reduce inflation. They suggested that if a monetary reform (a partial liberalization) can mobilize domestic savings and allocate them to efficient uses, as has been claimed; full financial liberalization may produce the optimal result of maximizing investment and further raising the average efficiency of capital. 


\subsection{Supply-Leading Hypothesis}

The supply leading hypothesis suggests that financial deepening fuels growth. The existence and development of the financial markets brings about a higher level of savings and investment and enhance the efficiency of capital accumulation. The contention of this hypothesis is that, a well-functioning financial institutions can promote overall economic efficiency, create and expand capital accumulation, transfer resources from traditional (non-growth) sectors to the modern growth inducing sectors and also promote a competent entrepreneur response in these modern sectors of the economy. Early economists like [36]; [31], have strongly supported the view of finance led caused relationship between finance and economic growth. These authors are of the opinion that causality proceeds from financial to economic development, it is only at a later stage that financial development leads on to growth.

\subsection{Demand-Following Hypothesis}

[37] was of the opinion that economic activity propels banks to finance enterprises. Thus, where enterprises lead, finance follows.

This hypothesis view is that the development of the financial markets is merely a lagged response to economic growth. This implies that any early efforts to develop financial markets might lead to a waste of resources which could be allocated to more useful purposes in the early stages of growth. As the economy advances, this triggers an increase demand for more financial services and thus leads to greater financial development. Some research work postulate that economic growth is a casual factor for financial development. According to them, as the real sector grows, the increasing demand for financial services stimulates the financial sector [11].

\subsection{Gap in the Literature}

Having examined both theoretical and empirical literatures in this study, it was discovered that there exists a gap in the literature arising from the fact that there are many literatures on the effect of financial deepening on economic growth without due consideration given to the "lubricant" that fuelled the growth, which is bank performance. Therefore this study intends to bridge the gap as put forth by economists and empirical studies on the effect of financial deepening on bank performance.

\section{Methodology}

\subsection{Research Design}

This study adopted descriptive research design to explore the relevance of financial deepening on banks performance and because it permitted the researcher to test specific hypotheses about the direction and magnitude of influences of variables such as financial deepening $\left(\mathrm{M}_{2}\right)$ /GDP ratio, credit to private sector-GDP ratio, and deposits liabilities-GDP ratio have on profitability. 
Some studies applied Person's Product Movement Correlation and especially the multiple regressions analytical model [11]. The panel Least Square of Simple Regression analysis was applied in this study because the data sets on the variables have both time series and cross-sectional dimensions.

\subsection{Data Sources}

The data employed in this study are secondary data. The data were extracted from relevant publications of the Central Bank of Nigeria (CBN) such as: CBN Statistical Bulletin, annual published financial statement of the selected banks and National Bureau of Statistics (NBS). The study covered a period of 22 years (1988-2012). The period chosen for the study encompasses most of the major reforms in the Nigeria financial system as explained in the introductory section of this paper.

Secondary data was employed as it is useful to the researcher in answering research questions about social issues and significantly aid advancement of the social sciences. The choice of secondary data was made as it is faster, reduces time wastages in data gathering, it is non-reactive, often available for re-analysis, it also provides a broad background and readily improves one's learning curve. In the words of [38], secondary data is neither better nor worse than the primary data; it is simply different. The source of the data is not as important as its quality and its relevance for particular purposes

\subsection{Method of Data Presentation}

The data on the indices of financial deepening and selected banks performance in Nigeria extracted from the secondary sources were presented in table with rows and column dimensions. The table showed the values of the variables over the period of study. The first row of the table showed the identifying nomenclatures of the financial deepening relevant indicators, while the first column showed the years of the period of study in chronological sequence. The remaining columns showed the values of the respective identified relevant indicators over the period of study.

\subsection{Method of Data Analysis}

Methods of descriptive and empirical analysis were used to analyze the data. The empirical investigation was based on a theoretical model of micro economic study of banking sector. Indeed, the financial sector in Nigeria is essentially constituted by banks and it is pertinent that a coherent study of financial deepening must consider the banking system. For this purpose, the theoretical model of [11] was adapted by taking into account the influence of financial deepening variables on banks performance. The model explains the theoretical link between financial deepening and factors related to economic growth by focusing on the real sectors of the economy.

Due to the assumed linearity of the model specified; Ordinary Least Squares (OLS) estimation method was employed to obtain the intercept and coefficients 
of the model. The estimates were used to determine the relationship between financial deepening and selected banks performance measurement. Also the estimates and relevant statistics were used to evaluate the models for consistency or otherwise with expectations, statistical significance and explanatory power.

\subsection{Hypothesized Relationships}

The hypothesized relationship is functionally expressed as follows:

$$
\operatorname{PRFT}(\mathrm{PBT})=f(\mathrm{FD})
$$

where:

PRFT $=$ Profitability,

PBT $=$ Profits before Tax,

$\mathrm{FD}=$ Financial Deepening.

Decomposing FD into its various components, the functional relationship becomes

$$
\operatorname{PRFT}(\mathrm{PBT})=f\left(\mathrm{FD}\left(\mathrm{M}_{2} / \mathrm{GDP}\right), \mathrm{RCPGDP}, \mathrm{RDLGDP}\right)
$$

where:

$\mathrm{FD}\left(\mathrm{M}_{2} / \mathrm{GDP}\right)=$ ratio of money supply $\left(\mathrm{M}_{2}\right) / \mathrm{GDP}$,

RCPGDP $=$ ratio of credits to Private Sector-GDP,

RDLGDP $=$ ratio of deposit liability-GDP,

GDP $=$ Gross Domestic Products at current basic prices .

\subsection{Analytical Model}

From the hypothesized relationship, the model following multiple regression model adapted from Onyemachi, (2012) was specified

$$
\operatorname{PRFT}(\mathrm{PBT})=\beta_{0}+\beta_{1} \mathrm{FD}\left(\mathrm{M}_{2} / \mathrm{GDP}\right)+\beta_{2} \mathrm{RCPGDP}+\beta_{3} \mathrm{RDLGDP}+\mu
$$

This was later broken to simple models as a result of the presence of multicollinearity and are thus, modified, estimated and evaluated:

$$
\begin{gathered}
\operatorname{PRFT}(\mathrm{PBT})=\beta_{0}+\beta_{1} \mathrm{FD}\left(\mathrm{M}_{2} / \mathrm{GDP}\right)+\mu \\
\operatorname{PRFT}(\mathrm{PBT})=\beta_{0}+\beta_{2} \mathrm{RCPGDP}+\mu \\
\operatorname{PRFT}(\mathrm{PBT})=\beta_{0}+\beta_{3} \mathrm{RDLGDP}+\mu
\end{gathered}
$$

$\beta_{0}$ is the intercept of the models. It captures the level of profitability of the selected banks can sustain in the absence of financial deepening.

$\beta_{i}(i=1,2,3)$ are respective coefficients of the associated financial deepening variables.

Each determined the nature of the relationship between the associated financial deepening index and profitability, as well as the magnitude of the effect of each on profitability.

$\mu$ is a random variable introduced in the models to accommodate the effect of any other factor that has influence on the selected bank's performance but not captured in the models. 


\subsection{A Priori Expectation}

A rise in the ratio of $\mathrm{FD}\left(\mathrm{M}_{2} / \mathrm{GDP}\right)$ was expected to have a positive effect on banks' profitability, such that as the ratio of money supply rises, banks' profitability increases since the ability of banks to make profits depends on the availability of stock of money held by these banks for transactions. Money supply was expected to grow geometrically while the GDP was to rise at arithmetical progression to pave way for a tremendous increase in the ratio of money supply which in turn pushes up banks' profitability. The ratio of credit to private sector-GDP was expected to also lead to an increase in banks' profitability. The income generated by banks depends on the amount of loan granted. Therefore, credit to private sector was expected to rise faster than the GDP, so as to have a positive impact on banks' profitability.

In another dimension, the ratio of deposits liabilities-GDP was expected to have a positive and significant effect on banks' ability to make profits, such that as both savings and time deposits including demand deposits (deposits on current accounts with the banks) rises, banks' profitability rises since demand deposits also has a base line which enables it to contribute significantly to banks' profits. Savings deposits, time and demand deposits were significant tools for banks profitability because it allows for banks to grant reasonable amount of such deposits as loans and advances out of which greater income were generated. As this kind of deposits rises faster than the GDP, the ratio of deposits liabilitiesGDP was expected to have a positive and significant impact on banks' profitability. Symbolically, the expectations were represented, thus: $\beta_{0}>0, \beta_{1}>0, \beta_{2}>0$, $\beta_{3}>0$.

\subsection{Estimation and Evaluation of the Model Parameters}

$\beta_{0}, \beta_{1}, \beta_{2}, \beta_{3}$, are model parameters while $\beta_{0}$ is the intercept. $\beta_{1}, \beta_{2}, \beta_{3}$ are the coefficients of the explanatory variables. Numerical values of the model parameters were obtained via the Least Square (LS) estimation technique. The choice of LS Technique was appropriate because of its, Best, Linear, Unbiased, and Efficiency (BLUE) property. Relevant statistical software was used to facilitate the estimation process. In the same vein, relevant statistics ( $t$-statistic and F-statistic) was employed, at the $5 \%$ level of significance of the coefficients (effects or relevance) of the financial deepening operationalize the hypotheses of the study, while the coefficient of determination (R-Squared) was used to determine the strength of financial deepening indices in explaining variations in profitability of the banks during the period of the study.

\subsection{Decision Criterion for t-Statistic}

Accept the hypotheses $\mathrm{H}_{\mathrm{O} 1}, \mathrm{H}_{\mathrm{O} 2}, \mathrm{H}_{\mathrm{O} 3}$, on the respective significant effects of ratio $\mathrm{FD}\left(\mathrm{M}_{2}\right) / \mathrm{GDP}$; ratio of credit to private sector-GDP; and ratio of deposit liabilityGDP on selected banks performance if probability associated with computed $t$-statistic is less than the level of significance that was used.

Reject the hypothesis $\left(\mathrm{H}_{\mathrm{O} 1}, \mathrm{H}_{\mathrm{O} 2}, \mathrm{H}_{\mathrm{O} 3}\right)$ on the respective significant effects ratio 
of financial deepening $\left(\mathrm{M}_{2}\right)$ /GDP; ratio of credit to private sector-GDP; and ratio of deposit liability-GDP on selected banks performance if probability associated with computed t-statistic is greater than the level of significance that was used.

\subsection{Decision Criterion for f-Statistic}

Accept the hypotheses $\left(\mathrm{H}_{\mathrm{O} 1}, \mathrm{H}_{\mathrm{O} 2}, \mathrm{H}_{\mathrm{O} 3}\right.$ ) $)$ on the overall significant effects of financial deepening on banks performance if probability associated with computed f-statistic is less than the level of significance that was used.

Reject the hypotheses $\left(\mathrm{H}_{\mathrm{O} 1}, \mathrm{H}_{\mathrm{O} 2}, \mathrm{H}_{\mathrm{O} 3}\right.$, $)$ on the overall significant effects of financial deepening on banks performance if probability associated with computed f-statistic is greater than the level of significance that was used.

\subsection{Empirical Analysis}

\subsubsection{Consistency of the Estimates with A-priori Expectations}

The estimated model shows that the ratio of FD $\left(\mathrm{M}_{2} / \mathrm{GDP}\right)$; ratio of credit to private sector-GDP and the ratio of deposit liability-GDP assumed positive signs while $\left(\beta_{1}=1.232>0 ; \beta_{2}=2.204>0\right.$; and $\left.\beta_{3}=1.648>0\right)$. These provided empirical evidence that financial deepening made positive contributions to the level of profitability of the selected banks. The positive coefficients of FD $\left(\mathrm{M}_{2} / \mathrm{GDP}\right)$, ratio of credit to private sector-GDP and ratio of deposit liability-GDP are consistent with the pre-estimation expectations about the effect of financial deepening on the selected banks profitability since the intercept sign are also positive. The estimates indicate that the ratio of credit to private sector-GDP contribute more to profitability of the selected banks followed by the ratio of deposit liabilityGDP and the ratio of FD $\left(\mathrm{M}_{2} / \mathrm{GDP}\right)$ respectively $\left(\beta_{2}=2.048>\beta_{3}=1.648>\beta_{1}=\right.$ 1.23).

\subsubsection{Significance of Overall Effect of Financial Deepening Contribution to Banks Performance (Profitability)}

The motive of this evaluation is to determine the statistical significance or otherwise of aggregate effect of financial deepening on banks performance during the period of the study. As a basis to test the central hypothesis and address the main research question and objective of the study, decision will be based on the F-Statistic and its p-value, specified level of significance and the decision rule as stated under the methodology.

Main Objective of the Study: To establish how financial deepening has affected banks' performance in Nigeria.

General Question: How has financial deepening affected the performance of banks in Nigeria?

Main Hypothesis: Financial Deepening has no impact on banks performance.

\section{Interpretation of the Result}

As shown in Table 1, the p-value of the F-Statistic associated with the overall effect of relevance of the contributions of financial deepening on bank perfor- 
Table 1. F-Statistic, P-Value, level of significance and decision.

\begin{tabular}{cccc}
\hline F-statistic & $\boldsymbol{P}$ Value & $\begin{array}{c}\text { Greater or Less than the } \\
\mathbf{0 . 0 5} \text { Level of Significance? }\end{array}$ & $\begin{array}{c}\text { Decision on Overall } \\
\text { Effect or Relevance }\end{array}$ \\
\hline 34.725 & 0.026 & Less & Significant \\
\hline
\end{tabular}

Source: SPSS output.

mance (profitability) is less than the level of significance (F-Stat $P$-value $=0.026$ $<0.05)$. This showed empirically that on the aggregate, the effect of financial deepening on banks performance in Nigeria is statistically significant. Therefore, on the basis of this analysis, it was concluded that financial deepening bears a statistically significant relationship with banks performance and consequently establishing the main research objective and answering the major research question.

\section{Discussion of Findings}

It was discovered that the coefficient of FD $\left(\mathrm{M}_{2} / \mathrm{GDP}\right)$ is $\beta_{1}=(1.23)$ affirms a positive relationship with bank performance. The adjusted $\mathrm{R}^{2}$ of 0.169 means that $16.9 \%$ of changes in bank performance is as a result of the financial deepening variable. The $p$-value shows 0.025 which is lesser than 0.05 level of significant. This implies that financial deepening has significantly impacted on the profitability of the selected banks, which invariably leads to economic growth. This is in line with the summation of [39] which found strong evidence that financial development is important for growth. Also [8], concluded that organizational factors influenced profitability more than economic factors.

It was also discovered that the coefficient of RCPGDP is $\beta_{2}=(2.048)$ explains a positive relationship with bank performance. The adjusted $\mathrm{R}^{2}$ which is 0.363 means that, ratio of credit to private sector contributed $36.3 \%$ to banks' profitability. The $p$-value shows 0.001 which is lesser than 0.05 level of significant. This means that ratio of credit to private sector has a positive significant relationship with banks' profitability of the selected banks as it relates to economic growth. This is consistent with [6] conclusion that a well-developed financial sector spurs overall high but sustainable growth of an economy.

It was discovered that the coefficient of RDLGDP is $\beta_{3}=(1.648)$ this shows a positive effect on profitability of the banks. The adjusted $R^{2}$ of 0.380 means that $38 \%$ of changes in bank performance is as a result of ratio of deposit liability. The $p$-value is 0.001 which is lesser than 0.05 level of significant. This implies that ratio of deposit liability has significantly impacted on the profitability of the selected banks, which invariably leads to economic growth. This is in line with the summation of [40], which concluded that the ratio of Central Bank assets to GDP falls as income rises while all other measures, rises.

The result of the analysis reveals that:

1) Financial deepening $\left(\mathrm{M}_{2} / \mathrm{GDP}\right)$ ratio had significant positive effect on profitability of the selected banks. This shows that as ratio of money supply increases banks' profits increases and the strength of the relationship is strong. 
2) Ratio of credit to Private Sector-GDP had positive and significant relationship with the profitability of the selected banks. This shows that the ratio of credit to private sector-GDP increases the selected banks' profits increases as well.

3) Deposit Liabilities-GDP ratio had positive effect on profitability of the commercial banks i.e. the more the RDLGDP increases the more the profitability and vice-versa.

4) On the aggregate, these determinants of financial deepening were found to exert significant effect on profitability of commercial banks. Thus the components of financial deepening are relevant and statistically significant in determining the profitability of the selected banks.

5) The multiple correlation coefficients indicate that there is a strong relationship between the components of financial deepening and banks profitability.

\section{Conclusions}

This study establishes that the components of financial deepening play key roles in determining the profitability of commercial banks in Nigeria and were found to be statistically significant. The study also established the relevance of specified components of financial deepening on profitability of the selected banks and also the aggregate considerations of all the components. It was discovered that the contribution to financial deepening was positive and significant on the aggregate.

Result of the analysis and finding thereof has provided some interesting insights that will enhance clearer understanding of financial deepening and profitability of commercial banks in Nigeria. This study concludes that the determination of banks profitability is influenced by all these components of financial deepening.

\section{Recommendations}

Based on the analysis, findings and conclusion thereof, the study proffers the following recommendations:

1) As was empirically carried out an increase in deposits liability automatically translate to an increase in bank performance. Measures should be put in place by the management team of these banks to encourage deposits (savings, fixed account and on current account), since accumulated deposits are made available for finance of investment opportunities which yield returns in terms of profitability.

2) Establishing more branches could be a better way of having access to more deposits even from the rural dwellers. The management of commercial banks in Nigeria should give due consideration to this aspect so that more deposits could mobilized from the grass for improved savings and improved financial development.

3) As empirically tested in this work, the ratio of credit to private sector exerts significant impact on banks profitability, therefore due consideration should be given to this sector rather than the government. In Nigeria, there has been under 
development of the real sector as a result of lack of funds from the financial sector to this sector also attributed to this is the pathetic situation in the country where government deficits that have to be financed by domestic resources provides an opportunity for the banking system to push funds into a relatively safer investment outlet than lending to the private sector. According to them, this has the capacity to push up lending rates and decrease the amount of resources channeled to private sector credit. Worse still, the banks rely on public fund to finance government borrowing; so it is a case of lending government fund to same government to generate safe return. These should be reversed by the management of Nigeria commercial banks.

4) Also financial deepening (M2/GDP) contributed in this research work to banks profitability. Government policy should therefore be geared towards strategically increasing money supply and promoting efficient capital market that will enhance overall economic efficiency, create and expand liquidity, mobilize saving, enhance capital accumulation, transfer resources from traditional sector to growth inducing sectors (such as manufacturing and industry, agriculture and services sectors) and also promote competent entrepreneurial response in various sectors of the economy. However, it is pertinent to ensure that it (money supply) does not lead to financial excessiveness.

\section{References}

[1] Donli, J. (2007) The State and Future of Banking Industry in Nigeria.

[2] Ron, B. (2012) Bank Financial Analysis. Richards College of Business, Accounting and Finance, Carrollton.

[3] Somoye, R. (2008) The Performance of Commercial Banks in Post Consolidation Period in Nigeria. An Empirical Review. European Journal of Economics, Finance and Administrative Science, 14, 62-73.

[4] Nnanna \& Dogo (1998) Interest Rate Reforms and Financial Deepening in Nigeria. http://www.researchgate.net/publication/22

[5] Soludo, C.C. (2004) Consolidating the Nigerian Banking Industryto Meet Development Challenges of the 21st Century. CBN Headquarter, Bankers' Committee, Abuja.

[6] Uchendu, O.A. (2005) Banking Sector Reforms and Bank Consolidation. The MalaysianExperience Bullion, 29, 9.

[7] Kunt, B. (2009) Financial Institutions and Markets across Countries and over Time Data and Analysis. World Bank, Wahsington DC.

[8] Gunu, U. (2010) Peformance Evaluation of Consolidated Banks in Nigeria by Using Non-Financial Measure. Interdisciplinary Journal of Research Business, 1, 72-83.

[9] Ajayi, M. (2005) Banking Sector Reforms and Bank Consoidation: Coneputal Framework. CBN Bullion, 29, 2-9.

[10] Ogbunuka, U.M. (2005) Banking Sector Reforms and Banking Consolidation: The Experience of Turkey. CBN Bullion, 29, 17-36.

[11] Onyemachi, C. (2012) An Empirical Analysis of Financial Deepening and Economic Growth (1986-2010). Ahmadu Bello University, Economics, Zaria.

[12] Rajan, R.G. and Zingales (2003) Saving Capitalism from Capitalists. Crown Business, New York. 
[13] Cameron, P. (1979) Banking in the Early Stages of Industrialization. Oxford University, New York.

[14] Oya, P.A. and Dama (2006) Financial Sector Deepening and Economic Growth: Evidence from Turkey. Bebek, Istanbul.

[15] Herve (2008) Financial Deepening without Financial Excesses. 43rd SEACEn Governor's Conference, Jakarta, 21-22 March 2008.

[16] Arestis, P.P. and Bassam (2002) The Impact of Financial Liberalization Policies on Financial Development: Evidence from Developing Economies. International Journal of Financial and Economics, 7, 102-121. https://doi.org/10.1002/ijfe.181

[17] Chen, B. (2000) Determinants of Economic of Growth in China: Private Enterprises, Edcuation and Openess. China Economic Review, 11, 1-5.

[18] Demetriades, P.O. (1996) Banking Sector Policies and Financial Development in Nepal. Oxford Bulletin of Economic and Statistics, 58, 355-372. https://doi.org/10.1111/j.1468-0084.1996.mp58002008.x

[19] Jovanovic, B. (1990) Financial Development, Growth and the Distribution of Income. Philladephia. http://www.econ.upenn.Edu/

[20] Demetriades, P.O. (1996) Financial Development, Economic Growth and Banking Sector Controls: Evidence from India. Economic Journal, 106, 359-374. https://doi.org/10.2307/2235252

[21] Bassam, K. (1976) Alternative Stabilization Policies for Less-Developed Economies. Journal of Political Economy, 84, 777-795.

[22] Demetriades and Luintel (1994) Financial Restraints in South Korean Miracle. Journal of Development Economics, 64, 459-479.

[23] Ahmad, A.B. (2010) Peformance Evaluation of Convention Banks in Pakistan by Using Non-Financial Measures. Interdisciplinary Journal of Contemporary Research in Business, 2, 140.

[24] Hammilton, O.I. and Godwin (2013) Does Financial Deepening Follow Supply Leading or Demand Following Hypothesis? A Critical Look at the Nigerian Evidence. Journal of Science and Technology, 5, 10-15.

[25] Christian, L.N. (2013) Financial Deepening Dynamics and Implication for Financial Policy Coordination in a Monetary Union: The Case of WAEMU. African Economic Conference 2013, Johannesburg.

[26] Osinsanwo, B.G. (2013) The Macroeconomic Effect of Financial Development on Economic Growth in Nigeria: A Long Run Analysis, 1970-2011. Journal of African Macroeconomic Review, 4, 227-245.

[27] King, R.G. and Levine (1993) Finance, Enterprenuership and Growth. Journal of Monetary Economics, 33, 513-542.

[28] Rajan, R. and Zingales, C.L. (1998) Financial Dependence and Growth. The American Economic Review, 88, 559-586.

[29] Oloyede, A. (1994) Banking Regulation in Nigeria: An Analytical Perspective. Lagos: CBN Economic and Financial Review, 32, 279-291.

[30] Ajibola, M.A. (2011) Casual Relationships between Financial Developemnt, Foreign Direct Investment and Economic Growth: The Case of Nigeria. International Journal of Business Administration, 2, 93-102.

[31] McKmnon, R.I. (1973) Money and Capital in Economic Development. The Brookings Institution, Washington DC.

[32] Shaw, E. (1973) Financial Deepening and Economic Development. Oxford University Press, London. 
[33] Galbis, V. (1997) Financial Intermediation and Economic Growth in Less Developed Countries: A Theoretical Approach. Journal of Development Studies, 13, 5872. https://doi.org/10.1080/00220387708421622

[34] Mathiesun, D.J. (1980) Financial Reform and Stabilization Policy in a Developing Economy. Journal of Development Economics, 7, 359-395.

[35] Capannelli, G.J. (2009) Developing Indicators for Regional Economic Integration and Cooepration. Asian Development Bank, No. 33.

[36] Schumpter, J.A. (1911) The Theory of Economic Development. Harvard University Press, Cambridge.

[37] Robinson, J. (1952) The Generalisation of the General Theory in the Rate of Interest and Other Essays. Macmillan, London.

[38] Scot, B. (2008) Fundamentals of Contemporary Business Communication, Houghton Mifflin, 2008.

[39] Demirgue-Kunt, A. (2001) Financial Structure and Economic Growth. MIT Press, Cambridge.

[40] Ndebbio, J.E.U. (2004) Financial Deepening, Economic Growth and Development: Evidence from Selected SSA Countries. African Economic and Research Consortium, RP142.

Submit or recommend next manuscript to SCIRP and we will provide best service for you:

Accepting pre-submission inquiries through Email, Facebook, LinkedIn, Twitter, etc. A wide selection of journals (inclusive of 9 subjects, more than 200 journals)

Providing 24-hour high-quality service

User-friendly online submission system

Fair and swift peer-review system

Efficient typesetting and proofreading procedure

Display of the result of downloads and visits, as well as the number of cited articles

Maximum dissemination of your research work

Submit your manuscript at: http://papersubmission.scirp.org/

Or contact jmf@scirp.org 